\title{
Discussion on Philosophical and Political Thought of Confucianism and Taoism of Wang Tong in the Sui Dynasty
}

\author{
Ye Ling \\ School of Marxism, Weinan Normal University; Shaanxxi Weinan 714000, China
}

\author{
Keywords: The Sui Dynasty, Wang Tong, Buddhism, Kingly Way Thought
}

\begin{abstract}
Wang Tong is an important thinker of the late Sui Dynasty, Confucianism, the pursuit of life to promote the doctrine of Confucius and Mencius. Stand in the position of Confucianism, put forward "Buddhism" thoughts, advocated the integration of three absorption and complement each other; advocate for "King" politics, "benevolence". Not only to promote the revival of Confucianism, but also opened the policy of benevolence and the Tang and Song dynasties in the Tang Dynasty to the song and Ming Dynasties absorbed two Buddhist teaching thoughts precedent, is an important figure in the history of Confucianism in the past.
\end{abstract}

\section{Introduction}

The Sui Dynasty was a short-lived Dynasty China social history, is at a turning point in the history of a dynasty to by the tumultuous short unification of Wei Jin Southern and Northern dynasties. Wang Tong was an important thinker living at this turning point in the dynasty. At this turning point, various social contradictions were re exposed after the war was flat. On the one hand, the war caused the moral and moral relationship to be reduced. The frequent war made the ruling order being broken the traditional Confucian ethics such as father and son, husband and wife, the relationship has been trampled and destroyed in the dynasties of turmoil. Therefore, the urgent need to reconstruct a new ethical order, in order to meet the needs of the unified dynasty; on the other hand, as the ideological ruling dynasties from Han Dynasty Confucianism, after getting into empty trivial chapters, the lack of rigorous thinking. While the two Buddhist teaching is in the Wei and Jin dynasties after the rapid development, to the traditional Confucianism with great impact and challenge [1-2]. In this situation, Wang Tong determined to restore Confucianism, and advocate the "King" to promote ethics and values of Confucianism and Taoism, and advocated to absorb the essence of Buddhism and Taoism two teaches, enhance the vitality of Confucianism thinking, to maintain the dominant position of confucianism. Although his thought did not have a great influence on his time, the significance of his later generations was very important. Therefore, it is necessary and meaningful to study Wang Tong's thought. Wang Tong's thought involves a wide range of ideas, and this article discusses his main ideas, philosophy and political thought.

\section{Wang Tong}

Wang Tong, Zi Zhong Yan Sui, Longmen east county (now Shanxi Wanrong county), was born in the Sui Dynasty Kai Huang four years (584 years), Suiti died in the great cause of thirteen years (617 years), his private Shi "wenzhongzhi". He was born in a family of officials. According to the people flooded by "Du wenzhongzhi family" said, the first world to Qi (now Shanxi Qixian) people, had Suijin room in Jiangdong, to the East, Shi Wei is in fifth ancestral. Father Wang long, the emperor had opened in the early Sui Dynasty, the son Dr. Daizhao cloud Longmen, to play "on" the rise and fall of the Sui Dynasty in seven, "said the pros and cons of six generations, is praised by the Sui dynasty [3]. Wang Wang Tong was so erudite through paternal teaching and influence deeply influenced by confucianism. At the age of 18, "Sifangzhizhi", traveling to ask, because in the knowledge, "not solve the six years old, so the tecload". The three years of the Sui Dynasty (603 years), Wang Tongnian, twenty, has generously helping people heart, West Changan, see Emperor Wen, on the "peace policy", "respecting the king, pushing the tyrant slightly, to this experience the 
ancient world in the palm to be shipped on justice." The emperor is very appreciate, the proposal to allow discussion without using the Duke. After the recommendation of the fellow townsmen, Xue Daoheng was taught to Shu county and Shu Wang Shilang, not very satisfied. Soon he retired to the country to write and lecture, and was determined to carry forward the Confucianism, the Ming Zhou and the Tao. He spent nine years studying by six, "continued six". He said: "more than a glimpse into Xunqin boy nine years away, meaning their ancestors service, Ji Zhongni heart, the world of things, the emperor, visible almost!" He in the Fen River, teach together until his death, the sea up to thousands of people. The several big politician Wei Zheng, Fang Xuanling, Du Ruhui, Chen Shuda, Li Jing, Wen, both the door. His brother Wang Ji, Wang is the name, the sun Wang Bo is young talent, can make good writing, known as "chutangsijie". The works of Wang Tong, according to Du Yan, a "present" theory, the "music theory", "continue book", "continued," poem "Jing", "Yi Yuan" and "praise" but not Xu Liujing, handed down, the existing is its disciple he and the students answers compiled notes the "said" (i.e. "wenzhongzhi") in ten volumes [4-5].

\section{Wang Tong's Philosophical and Political Thoughts}

Though Wang Tong was short in his life, he put forward many valuable ideas and ideas, which are scattered in his middle work, but the purpose is quite clear, which is mainly reflected in philosophy and political thoughts.

Wang Tong's philosophical thought

Wang Tong believes that "three religions can be one" in academic circles, which can be the fusion point of view. He is the Buddha competing long, Buddhism advocates harmony differences, that they should stop attacking each other, reflect the development trend of Taoism. Wang Tong believes in Confucianism only Confucianism to become the ruling ideology. He said: "I have seen thousands of years at the top above the sage, not if the Duke of Zhou yan. It is a large and the preparation, after the government has to follow; I see Qianzai and, if not Zhongni yan. Week is a political basis hole, Xiuwen criterion. It is clear that the politics is clear, the rite and music flourish, the political power is stable, and the people live and work. At this point, neither the Buddha nor the Tao can be replaced. This is Wang Tong three can be a basic premise of the.

Wang Tong "three religions can be one" that is based on two basic points. First, he believes that the "do not waste". On this issue, he not only Confucianism holding only the parochial prejudice, think three of the ruling class, are useful, have assistant content. The general scholars often take drastic exclusion of the Buddhist attitude, an important reason for its opposition to Buddhism is Buddhism "disastrous", such as Jin Chong Xuan appeared eight emperor worship Buddha, chaos, the country broken dead. In this regard, Wang Tong that can not be the downfall of the country, due to the influence of simple old buddha. "Shi Sheng and Qin Shi death, non Zhongni sin is. This is a crime that is not the sin of Lao Zhuang. "Yi" does not cloud the person, the way is not true. Jin and Liang's demise, ruler of his own fault. As a result they not really implemented the "Tao". Second, three religions also have defects [6]. He also admitted Buddhist sages' education, but after all, Buddhism is "western education", not to be modified is not suitable for Chinese conditions, like the cart cannot navigate in Mizusawa, Chinese hat is not suitable for wearing in the West on the head of the same. The righteousness not repair, filial piety does not stand for "immortal immortal Tao", is not conducive to the implementation of the performance of insatiably avaricious, enlightenment to the people. Although Wang Tong criticized Buddhism and Taoism fiercely, Wang Tong did not approve of the treatment of them with fierce means. In his view, Wei emperor, the Northern Zhou Dynasty and Buddhism not only to eliminate the influence of Buddhism, on the contrary, also promoted the development of Buddhism more quickly. Therefore, he believes that the best way is to talk about Sima, "the good Jiuliu" spirit, the three unify on the basis of Confucianism, do "through the change", namely the malpractice of the modification and transformation to each other to accommodate each other, which can make the "no harm", "and table nine domains, together to discuss national affairs [7]. Wang Tong in the Confucianism on the basis of the integration of three religions thought, recognize three independent values on the one hand, on the other hand, stick to the position of Confucianism, not only promoted the revival of Confucianism in Sui and Tang 
Dynasties, and Neo Confucianism absorbed two Buddhist teaching.

\section{Wang Tong's Political Thought}

Wang Tong's political concern is to set up a feudal state that is able to carry out the politics of kingship and adapt to a unified multi-ethnic country. So his political thought is to carry out the politics of kingcraft. He often saves the dead to the ancients as a way of motivating his ambitions through writing and trying to achieve his ambitions. In addition to the "said", with eight or nine years of "Six Classics" (lost), advocate benevolent politics [8-9].

"Wang Daopian" is the first part of the "middle theory". He thought that the king should be "Yiyin Duke's road", "Duke Confucius", namely Confucianism advocates benevolent, to Germany first, then the punishment "against" as a punishment and abandon virtue". The specific contents include the following aspects:

First, respected three five permanent members. When Wang Tong visited the temple of Confucius, he exclaimed, "great! Jun Jun Chen, father and son, brother, brother, husband wife wife, master of power. It is in conformity with the Tai Chi, and the divine way is parallel! " Is Syria Wuchang, three cardinal guides, strict hierarchical order.

Second, publicize the letter of benevolence and righteousness. Wang Tong once said: "the Li mi Lixin righteousness, I can lie on the lonely; I do not force, language." He stressed | righteousness. Think "benevolence, what does it teach?" The first king is the moral and the ritual and music. It is required that the rulers "do the benevolence and righteousness". He also paid great attention to the "Rites" of the feudal hierarchy [10]. He thinks "rite, the gate of its emperor?" What does it mean? So it can be identified, and the people will be determined. That gift is social role is mainly to maintain social order, establish the correct specification for the behavior of people, establish harmonious interpersonal relationship paradigm set, pecking order. So he asked the people must follow the ceremony, "crown crown is read, read read only funeral marriage wedding, funeral, funeral funeral is read, the guest read, read military salute, a gentleman does not violate the ritual of the end of his life."

Thirdly, promote the king of politics. Wang Tong also regarded the three generation saint as the ideal politics, but he thought that the three generation of law was not effective, so he was replaced by the Han Dynasty. He said: "the world in three generations of the legal system, the final state in danger. If not, the system of the Han Dynasty? Not to Han system auxiliary day Cheng has chaos." The emperor said: "the two kings and I shall see it. she will be the Han Dynasty? Great is the Lord. There was no ambition in the four hundred years. Is it popular with people? The end of the ritual is also to kings." In order to carry out his ideal kingly way, Wang Tong advocated changing the real politics. He said "through the transformation, there are no disadvantages in the world, but there are no good teachers in the world.

Wang Tong's kingly way of political thought is in line with the requirements of the times. It reflects the good wishes of people at that time hoping for a peaceful and mild life, reflecting the social and political ideals of Confucian intellectuals. Although at the time the reality cannot be fully realized, but has the constructive affect on the politics in early Tang dynasty. His famous students such as Wei Zheng, is the Tang Dynasty founding entrepreneurs and "Zhenguan" participants had his thoughts in the early Tang Dynasty and founding "Zhenguan" plays an important role.

\section{Conclusion}

Wang Tong spent his life dedicated to the transformation of Confucianism and the revitalization of the work, he advocated the "King", "benevolence", advocate "Buddhism", these ideas are for future generations of thinkers inherited, reform, develop. He opened the Tang and Song Dynasties benevolent theory first, pointed out the direction for the revitalization of Confucianism, has certain enlightenment significance to the development of Neo confucianism. He is the academic belief to his spirit inspired generations will continue to carry forward the Confucian Confucianism; especially his "world not to easily Yimin life" thought, very valuable at the time, even if there is a 
high value in today, we should inherit and carry forward. Therefore, Wang Tong is worthy of an important character in the history of Confucianism.

\section{References}

[1] [Tang] Du Yan. Wen zhong zi Family[M]. Shanghai: Shanghai ancient books publishing house, 1986.

[2] [Sui] Wang Tong. Zhong said. Kingcraft [M]. Beijing: China Book Bureau, 1985.

[3] [Sui] Wang Tong. Zhong said. Heaven and earth [M]. Beijing: China Book Bureau, 1985.

[4] [Sui] Wang Tong. Zhong said. Zhou gong [M]. Beijing: China Book Bureau, 1985.

[5] [Sui] Wang Tong. Zhong said. Servicing the king [M]. Beijing: China Book Bureau, 1985.

[6] [Sui] Wang Tong. Zhong said. Rites and Music [M]. Beijing: China Book Bureau, 1985.

[7][Sui] Wang Tong. Zhong said. The Prime Minister of Wei state[M]. Beijing: China Book Bureau, 1985.

[8] [Sui] Wang Tong. Zhong said. Guan Lang[M]. Beijing: China Book Bureau, 1985. 